\title{
NEW APPROACH IN DETERMINING IBRUTINIB IN HUMAN PLASMA BY HPLC-DAD AND APPLICATION OF THE METHOD IN A PRELIMINARY PHARMACOKINETIC STUDY
}

\author{
DANIELA MARIA CROITORU ${ }^{1}$, COSTEL-VALENTIN MANDA ${ }^{1 *}$, MIHAIL-VIRGIL \\ BOLDEANU $^{2}$, IONELA ROTARU ${ }^{2}$, SIMONA-DANIELA NEAMȚU ${ }^{1}$, JOHNY NEAMȚU ${ }^{1}$, \\ OCTAVIAN CROITORU ${ }^{1}$
}

${ }^{1}$ Faculty of Pharmacy, University of Medicine and Pharmacy of Craiova, Petru Rareș Street, 200638, Craiova, Romania

${ }^{2}$ Faculty of Medicine, University of Medicine and Pharmacy of Craiova, Petru Rareș Street, 200638, Craiova, Romania

*corresponding author: valimanda052@gmail.com

Manuscript received: December 2019

\begin{abstract}
A simple, sensitive and specific liquid chromatographic method is developed and validated for qualitative and quantitative analysis of ibrutinib in human plasma. Liquid-liquid extraction with ethyl acetate is used for sample preparation within this method. Reverse phase high performance liquid chromatography with diode array detection (RP-HPLC-DAD) analysis is performed which employs a C18 Hypersil GOLD column with a mobile phase acetonitrile: methanol: buffer solution pH 4.7 sodium acetate $10 \mathrm{mM}$ and acetic acid $10 \mathrm{mM}, 40: 20: 40(\mathrm{v} / \mathrm{v} / \mathrm{v})$ with isocratic elution at a flow rate of $1 \mathrm{~mL} / \mathrm{min}$. Regarding sample preparation procedure, protein precipitation was investigated and different extraction solvents or extraction conditions were optimized. Selectivity and sensibility were also improved in order to accurately determine low concentrations of ibrutinib by correct selection of both mobile phase and detection wavelength used for quantitation.
\end{abstract}

\section{Rezumat}

A fost dezvoltată şi validată o metodă cromatografică de lichide simplă, sensibilă și specifică pentru analiza calitativă şi cantitativă a ibrutinibului în plasma umană. Extracția lichid-lichid cu acetat de etil este utilizată pentru pregătirea probelor în cadrul acestei metode. Este utilizată o metodă cromatografică de lichide de înaltă performanță cu faze inverse cuplată cu un detector cu rețea de diode (RP-HPLC-DAD), care folosește o coloană C18 Hypersil GOLD cu o fază mobilă acetonitril: metanol: soluție tampon pH 4,7 acetat de sodiu $10 \mathrm{mM}$ și acid acetic $10 \mathrm{mM}, 40: 20: 40$ (v/v/v) cu eluție izocratică la un debit de $1 \mathrm{~mL} / \mathrm{min}$. În ceea ce privește procedura de pregătire a probei, a fost investigată precipitarea proteinelor și au fost optimizați diferiţi solvenți sau condiții de extracție. Selectivitatea și sensibilitatea au fost, de asemenea, îmbunătățite pentru a determina cu precizie concentrații scăzute de ibrutinib prin selectarea corectă a fazei mobile și a lungimii de undă de detecție utilizate pentru cuantificare.

Keywords: ibrutinib, lidocaine, human plasma, HPLC-DAD

\section{Introduction}

Ibrutinib (Ibr) is a potent inhibitor of Bruton tyrosine kinase (BTK) and is proved to be very efficient in Bcell malignancies. BTK was first described by Ogden Bruton, hence the name, as being deficient in X-linked agammaglobulinaemia, a congenital disorder. BTK is involved in B-cell antigen receptor signalling pathways, with the role of amplifying receptor-nucleus signals [1]. Malignant cells transformed into B lymphoproliferations are dependent on the signals received by the B-cell receptor, which interfere with their survival, migration and proliferation. From this, the hypothesis emerged that blocking the signalling pathway mediated by BTK would block the proliferation and survival signals of the neoplastic cells, thus being a targeted therapy. Moreover, BTK is an important component of tumour microenvironment for certain myeloid populations, which has recently sparked interest in the use of
Bruton kinase inhibitors and in solid neoplasms, not only in B lymphoproliferations [1, 2, 9].

Ibr was approved in medical practice in 2013, initially in USA, in patients with relapsed or refractory mantle area lymphoma. One year later it is approved as secondline therapy in patients with relapsed/refractory chronic lymphatic leukaemia. Because the results were excellent, durable and the treatment was well tolerated, from 2016 it was approved for first line therapy in high risk chronic lymphocytic leukaemia. At the end of 2014, Ibr is approved by the EMA (European Medical Agency) in Europe with the same two indications, and from 2015 in the treatment of patients with Waldenstrom macroglobulinaemia. Since 2017, the indication for recurrent/refractory marginal zone lymphoma has been approved in USA, which received previous therapy with anti-CD20 monoclonal antibodies [5, 7]. 
FARMACIA, 2020, Vol. 68, 4

The study that was the basis for the approval of Ibr for the clinical use was the RESONATE study, which enrolled relapsed/refractory patients with chronic lymphocytic leukaemia/diffuse lymphocytic lymphoma, who received at least one previous treatment line and who are not candidates for purine analogues (Fludarabine), either because they have progression of the disease after a short period of free disease after chemoimmunotherapy, or because of the associated comorbidities. Patients were randomized into two groups: patients receiving $420 \mathrm{mg}$ of $\mathrm{Ibr}$ continuously until disease progression or onset of intolerance and patients receiving 12 doses of Ofatumumab (monoclonal anti-CD20 antibody of the second generation) for 24 weeks. Patients receiving Ibr had a $90 \%$ reduction in the risk of progression and a $57 \%$ reduction in the risk of death $[4,10]$. Excellent results were also confirmed by the RESONATE 2 study comparing Ibr with Chlorambucil, in the first line, in elderly patients over 65 years with comorbidities, who do not tolerate RituximabFludarabine-Cyclophosphamide (RFC) type chemoimmunotherapy. Overall, survival was $82 \%$ in the Ibr group, compared to only $35 \%$ in the Leukeran group. After administration, which should be at the same time every day, one hour before meal, with a large glass of water (to avoid grapefruit juice and oranges from Seville), Ibr is absorbed rapidly in $1-2$ hours. Bioavailability, according to the literature, is $2.9 \%$ and it doubles postprandially. The results were approximately similar for all B-malignant lymphoproliferations in which Ibr therapy is administered. The half-life is 4 - 6 hours $[3,15]$.

Ibr is metabolized by cytochrome P450, mainly by the enzyme 3A4 (CYP3A4). Therefore, the concomitant use with Ibr of cytochrome $\mathrm{P} 450$ inhibitor drugs such as ketoconazole, which may increase Ibr exposure up to 29 times, should be avoided. Related to other cytochrome P450 inhibitors (posaconazole, clarithromycin, voriconazole), in situations where it is necessary to administer them, it is recommended to discontinue the administration of Ibr for 7 days. Other drugs that moderately inhibit cytochrome P450 such as erythromycin, ciprofloxacin do not require discontinuation, but dose reduction to $280 \mathrm{mg} /$ day is recommended. On the other hand, the inducers of cytochrome P 450 may decrease the plasma concentration of Ibr and should also be avoided: rifampicin, phenytoin, herbal preparations containing St. John's Worth [8, 11, 18].

Since its first authorization in October 2014, many works regarding qualitative and quantitative determination were presented so far in the literature. Some authors present Ibr quantification in pharmaceuticals in degradation studies under stress conditions by liquid chromatography - mass spectrometry (LC-MS) and high resolution nuclear magnetic resonance (HR-NMR) [16]. Rood et al. [12-14] quantify Ibr and its dihydrodiolmetabolite in plasma by LC-MS/MS and apply this method in mouse pharmacokinetic studies. Other authors [17] present a LC-MS/MS analysis of Ibr in rat plasma, which also involves a pharmacokinetic study. To our knowledge, only a few papers presented so far in the literature, combine HPLC technique with diode array detection (DAD) which was fully validated for the determination of Ibr $[6,19]$ with a lower limit of quantitation (LLOQ) of 5 and $10 \mathrm{ng} / \mathrm{mL}$, respectively. The authors did not apply this method to real plasma samples, which could demonstrate the application of the method for the detection of low concentrations of the drug.

The purpose of our study was to develop and validate a simple, sensitive and reliable HPLC-DAD method for the quantitative determination of Ibr in human plasma. The method was successfully applied in a preliminary pharmacokinetic study involving five patients in chronic treatment with Ibr.

\section{Materials and Methods}

\section{Chemicals and Reagents}

Ibr [1-[(3R)-3-[4-amino-3-(4-phenoxyphenyl)-pyrazolo[3,4-d]pyrimidin-1-yl]-piperidin-1-yl]-prop-2-en-1one] was purchased from Biomedica Medizinprodukte (Romania). Lidocaine [ $N$-(2,6-dimethylphenyl)- $N^{2}, N^{2}$ diethylglycinamide], the internal standard (IS) was obtained from Sigma Aldrich. Sodium carbonate and sodium acetate came from Merck. Pure HPLC solvents (water, acetonitrile, methanol, ethyl acetate, ethyl ether and acetic acid) were also purchased from Merck.

Chromatographic System and Conditions

HPLC analysis was performed with a Thermo Finnigan Surveyor HPLC System equipped with a photodiode array detector. Separation was achieved using an octadecyl reversed phase column Hypersil GOLD (Thermo Scientific), with dimensions $250 \mathrm{~mm}$ x $4.6 \mathrm{~mm}$, particle size $5 \mu \mathrm{m}$. An optimized isocratic elution was performed at a flow rate of $1 \mathrm{~mL} / \mathrm{min}$ with a mobile phase consisting of acetonitrile:methanol:buffer solution $\mathrm{pH} 4.7$ sodium acetate $10 \mathrm{mM}$ and acetic acid $10 \mathrm{mM}$, 40:20:40 (v/v/v). The monitored wavelength range was $190-380 \mathrm{~nm}$, with a discrete channel at $215 \mathrm{~nm}$. All acquisition data and chromatograms were processed with ChromQuest Data Software 4.2.34.

Preparation of Stock and Standard Solutions

Stock solutions of Ibr and IS free base at a concentration of $1 \mathrm{mg} / \mathrm{mL}$ were prepared in methanol, stored at $-20^{\circ} \mathrm{C}$ and renewed every three months. Working solutions $(20 \mu \mathrm{g} / \mathrm{mL})$ were made by diluting these solutions with methanol, kept at $4^{\circ} \mathrm{C}$ and refreshed after 30 days. Sample Preparation Procedure

The previously frozen plasma is thawed at room temperature prior to analysis. The working procedure requires $1 \mathrm{~mL}$ human plasma which is spiked with the appropriate volumes of working solution or further dilutions in methanol, in order to obtain the concentrations of the calibration standards (CS) $(1,2,5,10,30$ and $50 \mathrm{ng} / \mathrm{mL}$ for Ibr and $30 \mathrm{ng} / \mathrm{mL}$ for IS) and the 
FARMACIA, 2020, Vol. 68, 4

validation standards (VS) $(2,10$ and $30 \mathrm{ng} / \mathrm{mL}$ for Ibr and $30 \mathrm{ng} / \mathrm{mL}$ for IS). Then, $0.3 \mathrm{~mL} 1 \mathrm{M}$ sodium carbonate solution and $2 \mathrm{~mL}$ ethyl acetate were added. The samples were gently shaken for $2 \mathrm{~min}$ and then centrifuged for $5 \mathrm{~min}$ at $5000 \mathrm{rpm}$. The upper organic layer was transferred into a conical vial and evaporated to dryness under a gentle stream of nitrogen at ambient temperature. $200 \mu \mathrm{L}$ mobile phase were added to dissolve the residue and $20 \mu \mathrm{L}$ of the reconstituted solution was manually injected into the chromatographic system.

Acquisition of Plasma Samples

Our preliminary pharmacokinetic study was performed on five patients with chronic treatment with Ibr. Our research complies with the Declaration of Helsinki and the subjects have given their informed, written consent regarding acquisition of plasma samples. Venous blood samples $(2 \mathrm{~mL})$ were collected by using a catheter, in special vacutainers that contain potassium EDTA powder (an anticoagulant). The samples were achieved before the daily dose and then after administration of $420 \mathrm{mg} \mathrm{Ibr}$, every two hours (at 0, 2, 4, 6, 8, 10 and $12 \mathrm{~h}$ ). Blood samples were centrifuged for 10 minutes at $5000 \mathrm{rpm}$, for the separation of plasma, the paraclinical investigations being performed on the obtained

plasma samples. Plasma samples were stored at $-20^{\circ} \mathrm{C}$ until analysis.

\section{Results and Discussion}

\section{Extraction procedure}

In order to detect the low concentrations of the drug in real plasma samples collected from patients, the volume of plasma required for extraction was $1 \mathrm{~mL}$. Lower volumes did not provide the necessary quantity of drug and consequently, the sensibility of the method was not high enough for quantitation.

The first step in performing a proper extraction is adjusting the $\mathrm{pH}$ of the sample. The compounds present alkaline properties, the pKa values for Ibr and IS are 6.58 and 7.75 , respectively. Therefore, creating an alkaline environment is mandatory for a proper liquidliquid extraction, both compounds being non-ionized in this case and extracted with a higher rate in the organic solvent. The extraction recoveries were found to be maximum by using a $1 \mathrm{M}$ sodium carbonate aqueous solution ( $\mathrm{pH} 10)$. Regarding the extraction solvents, mixtures of hexane with isoamyl alcohol in different ratios, ethyl ether, acetonitrile or ethyl acetate were investigated. The best results in term of extraction recovery of the analyte and IS were obtained by using ethyl acetate as extraction solvent.

Table I

Recovery obtained with different extraction solvents $(n=5)$

\begin{tabular}{|c|c|c|c|}
\hline \multirow[t]{2}{*}{ Extraction solvent } & \multirow{2}{*}{$\begin{array}{c}\text { Target concentration } \\
(\mathrm{ng} / \mathrm{mL})\end{array}$} & \multicolumn{2}{|c|}{ Extraction recovery $\%$} \\
\hline & & Ibr & IS \\
\hline \multirow[t]{3}{*}{ Hexane: isoamyl alcohol 80:20 } & 2 & 41 & - \\
\hline & 10 & 43 & - \\
\hline & 30 & 42 & 45 \\
\hline \multirow[t]{3}{*}{ Hexane: isoamyl alcohol 90:10 } & 2 & 41 & - \\
\hline & 10 & 42 & - \\
\hline & 30 & 41 & 46 \\
\hline \multirow[t]{3}{*}{ Ethyl ether } & 2 & 59 & - \\
\hline & 10 & 59 & - \\
\hline & 30 & 58 & 55 \\
\hline \multirow[t]{3}{*}{ Acetonitrile } & 2 & 61 & - \\
\hline & 10 & 61 & - \\
\hline & 30 & 62 & 59 \\
\hline \multirow[t]{3}{*}{ Ethyl acetate } & 2 & 89 & - \\
\hline & 10 & 92 & - \\
\hline & 30 & 94 & 92 \\
\hline
\end{tabular}

The extraction recovery of Ibr was calculated as the percentage ratio between the peak areas obtained for plasma samples spiked with known quantities corresponding to VS, processed according to the sample preparation procedure and the peak areas obtained by direct injection of the same quantities of analyte dissolved in $200 \mu \mathrm{L}$ mobile phase $(\mathrm{n}=5)$. Table I reveals the mean results obtained for the mentioned solvents for the three concentrations ranges.

Chromatographic separation

Two chromatographic columns, both octadecyl reversed phase Hypersil GOLD (Thermo Scientific), particle size $5 \mu \mathrm{m}$, with dimensions $150 \mathrm{~mm} \times 4.6 \mathrm{~mm}$ and $250 \mathrm{~mm}$ x $4.6 \mathrm{~mm}$ i.d. were investigated. The shorter column did not provide the necessary selectivity and the separation resolution was low in this case. The $250 \mathrm{~mm}$ length column was finally chosen for this analysis, because the matrix effect was cancelled by increasing analysis time.

The mobile phase is also important for the analysis. We investigated a basic mobile phase $(10 \mathrm{mM}$ solution ammonium acetate: acetonitrile, adjusted to $\mathrm{pH} 10$ with ammonia) which was not satisfactory in terms of selectivity and resolution which provided long analysis 
(about 20 min). Then, we decided to change the $\mathrm{pH}$ of mobile phase by using a buffer solution $\mathrm{pH} 4.7$ (sodium acetate $10 \mathrm{mM}$ and acetic acid $10 \mathrm{mM}$ ) mixed with acetonitrile and the retention times shortened, but resolution diminished. To resolve this problem, the effect of different ratios of methanol in the mobile phase was tested. Methanol improves the repartition of the analytes between mobile and stationary phases and consequently, the peak shape. Retention time decreases to $10.5 \mathrm{~min}$ when the ratio of methanol in the mobile phase was $20 \%$.

Peak identity was verified both by means of retention time (RT $10.50 \mathrm{~min}$ ) and spectrum of Ibr. The spectrum reveals two wavelengths which present maximum absorbance (215 and $258 \mathrm{~nm}$ ). For quantitation, the maximum wavelength $(215 \mathrm{~nm})$ was utilized, as there were no interferences with other plasma compounds. The percentage of methanol in the mobile phase and the low detection wavelength do not increase the baseline noise and do not decrease selectivity. Validation data

Calibration curve standards were processed in accordance to the sample preparation procedure previously presented. The CS concentrations were 1, 2, 5, 10, 30 and 50 $\mathrm{ng} / \mathrm{mL}$ Ibr and $30 \mathrm{ng} / \mathrm{mL}$ for IS. The standards were five times prepared and analyzed. Linear regression method was used for analysis. The calibration curve was obtained by graphically plotting the ratio peak areas of analyte and IS, determined at $215 \mathrm{~nm}$ to the concentration of Ibr in the sample. The concentrations in the unknown plasma samples were determined by

applying the linear regression curve equation to the ratio peak area. The correlation coefficient $\left(\mathrm{R}^{2}\right)$ demonstrates a good linearity of the results in the studied concentration range. Lower limit of quantitation (LLOQ) was established as the lowest plasma concentration for which the signal to base line noise ratio on the chromatogram is at least 10:1, and the precision expressed as relative standard deviation (RSD) did not exceed 15\%. LLOQ was found to be $1 \mathrm{ng} / \mathrm{mL}$ and was the first point of the calibration curve.

Regarding the stability of the analyte and IS in the stock and working solutions, the evaluation was performed under storage conditions $\left(4^{\circ} \mathrm{C}\right)$ for 30 days for the three concentrations of VS. The stability was evaluated by comparing them with freshly prepared solutions and was $97-104 \%$. Plasma samples were kept at $20^{\circ} \mathrm{C}$ until analysis and it was necessary to evaluate the freeze-thaw stability $(\mathrm{n}=5)$. The stability for three freeze-thaw cycles was determined for a three months period for all three concentration levels of VS and the values were between $96-102 \%$.

In terms of accuracy and precision, the results are presented in Table II, both intra-day and inter-day. The accuracy (recovery) was determined as the percentage ratio between the average found concentration (obtained by calculus from the calibration curve) and the spiked concentration and it was found to be more than $85 \%$. Precision was expressed as RSD and it was calculated as a percentage ratio between the standard deviation and the average found concentration. All values were less than $15 \%$, including LLOQ.

Table II

Accuracy and precision data $(\mathrm{n}=5)$

\begin{tabular}{|l|c|c|c|c|c|}
\hline \multirow{2}{*}{ Analyte } & \multirow{2}{*}{$\begin{array}{c}\text { Target concentration } \\
(\mathrm{ng} / \mathrm{mL})\end{array}$} & \multicolumn{2}{c|}{ Accuracy \% } & \multicolumn{2}{c|}{ Precision \% } \\
\cline { 2 - 6 } & 2 & Intra-day & Inter-day & Intra-day & Inter-day \\
\hline \multirow{3}{*}{ Ibr } & 10 & 88.36 & 88.02 & 13.59 & 13.79 \\
\cline { 2 - 6 } & 30 & 95.67 & 94.98 & 9.35 & 9.65 \\
\cline { 2 - 6 } & 30 & 97.69 & 96.37 & 6.59 & 7.01 \\
\hline Lidocaine (IS) & 95.56 & 94.89 & 7.36 & 7.42 \\
\hline
\end{tabular}

\section{Preliminary pharmacokinetic study}

The applicability of the method in determining Ibr concentration in real plasma samples was demonstrated by performing a preliminary pharmacokinetic study. In our group, five patients diagnosed with chronic lymphocytic leukaemia were included. Patients were administered $420 \mathrm{mg}$ Ibr daily (three $140 \mathrm{mg}$ tablets). Patients involved in this study, the first patient two years ago and the most recent two months ago, were monitored clinically and paraclinically. Most of them tolerated the drug very well, with no grade 3 or 4 adverse effects, which would require the reduction/ discontinuation of administration of the drug. Two of them developed episodes of atrial fibrillation, none of which were recorded with heart disease prior to beginning of therapy. For the first patient, we decided to stop the therapy after about 5 months due to the recurrence of atrial paroxysmal fibrillation, considering that the risk outweighs the benefit of continuing the therapy. In the second case, the first episode of atrial fibrillation was recorded without the need for anticoagulant therapy and is carefully monitored, without the need for discontinuation of Ibr administration. Mean plasma concentration \pm standard deviation (SD)/ time chart for the patients involved in this study is presented in Figure 1.

The maximum plasma concentration $\left(\mathrm{C}_{\max }\right.$ mean $\left.\pm \mathrm{SD}\right)$ was found to be $7.35 \pm 0.24 \mathrm{ng} / \mathrm{mL}$ at maximum time concentration $\mathrm{T}_{\max }$ of $4 \pm 0.06 \mathrm{~h}$ after administration, with a mean half-life $T_{1 / 2}$ of $7.88 \pm 0.08 \mathrm{~h}$. Area under the curve from time 0 to $24 \mathrm{~h}\left(\mathrm{AUC}_{0-24}\right)$ was $77.71 \pm$ $2.17(\mathrm{~h} * \mathrm{ng}) / \mathrm{mL}$, as presented in Table III. 


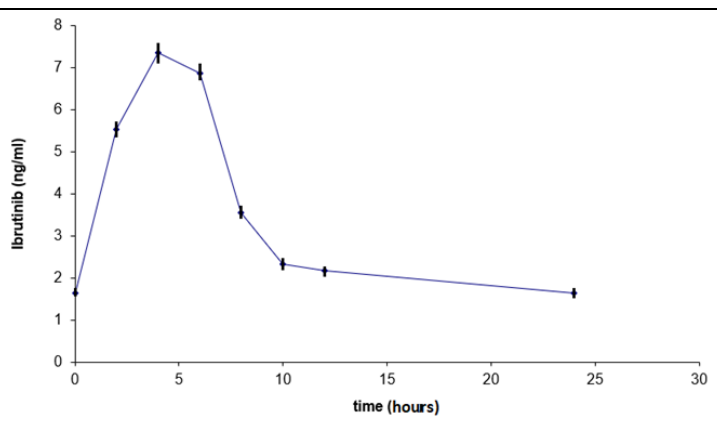

Figure 1.

Mean plasma concentration/time profile for five patients $( \pm$ SD) after chronic administration of Ibr (420 mg daily)

\section{Table III}

Pharmacokinetic parameters of Ibr after oral administration $(\mathrm{n}=5)$

\begin{tabular}{|l|c|}
\hline \multicolumn{1}{|c|}{ Parameter } & Mean $\pm \mathrm{SD}$ \\
\hline $\mathrm{C}_{\max }(\mathrm{ng} / \mathrm{mL})$ & $7.35 \pm 0.24$ \\
\hline $\mathrm{T}_{\max }(\mathrm{h})$ & $4 \pm 0.06$ \\
\hline $\mathrm{T}_{1 / 2}(\mathrm{~h})$ & $7.88 \pm 0.08$ \\
\hline $\left.\mathrm{AUC}_{0-24}(\mathrm{~h} * \mathrm{ng}) / \mathrm{mL}\right)$ & $77.71 \pm 2.17$ \\
\hline
\end{tabular}

Compared to previous studies published in the literature, the bioavailability in our research group is $3.8 \%$. The maximum plasma concentration was reached at approximate 4 hours after administration and halved in the next 4 hours, respectively 8 hours after administration.

\section{Conclusions}

Within this paper, a fully validated method for the Ibr analysis in human plasma was presented. The method consists of a liquid-liquid extraction as sample preparation method. The selectivity of the method is not influenced by the high percentage of methanol in the mobile phase or the low detection wavelength. Validation data, including limit of quantitation, linearity, accuracy, precision and stability tests qualify this method for determining the very low levels of the drug in human plasma. In order to demonstrate the suitability of the method to real biological samples, a preliminary pharmacokinetic study was performed. The method involves a relatively cheap chromatographic equipment which is affordable to any laboratory.

\section{Conflict of interest}

The authors declare no conflict of interest.

\section{References}

1. Australian Public Assessment Report for ibrutinib, Janssen-Cilag Pty Ltd Pm-2014-02780-1-4 Final 2 February 2016.

2. Barr P, Robak T, Owen C, Tedeschi A, Bairey O, Bartlett N, Burger J, Hillmen P, Coutre S, Devereux S, Grosicki S, Mccarthy H, Li J, Simpson D, Offner F, Moreno C, Zhou C, Styles L, James D, Kipps TJ, Ghia P, Oral Presentation at The $58^{\text {th }}$ Ash Annual
Meeting \& Exposition, 3-6 December 2016; San Diego, CA, USA.

3. Burger JA, Tedeschi A, Barr P.M, Robak T, Owen C, Ghia P, Bairey O, Hillmen P, Bartlett NL, Li J, Simpson D, Grosicki S, Devereux S, Mccarthy H, Coytre S, Quach H, Gaidano G, Maslyak Z, Stevens DA, Janssens A, Offner F, Mayer J, O’Dwyer M, Hellmann A, Schuh A, Siddiqi T, Polliack A, Tam CS, Suri D, Cheng M, Clow F, Styles L, James DF, Kipps TJ, For The Resonate-2 Investigators, Ibrutinib as Initial Therapy for Patients with Chronic Lymphocytic Leukemia. N Engl J Med., 2015; 373(35): 2425-2437.

4. Byrd JC, Brown JR, O'Brien S, Barrientos JC, Kay NE, Reddy NM, Coutre S, Tam CS, Mulligan SP, Jaeger U, Devereux S, Barr PM, Furman RR, Kipps TJ, Cymbalista F, Pocock C, Thornton P, CaligarisCappio F, Robak T, Delgado J, Schuster SJ, Montillo M, Schuh A, de Vos S, Gill D, Bloor A, Dearden C, Moreno C, Jones JJ, Chu AD, Fardis M, McGreivy J, Clow F, James DF, and Hillmen P, for the RESONATE Investigators*, Ibrutinib versus ofatumumab in previously treated chronic lymphoid leukemia. $N$ Engl J Med., 2014; 371(3): 213-223.

5. Ciocan LM, Danăilă L, Stănculescu DE, Neamțu SD, Mateescu OG, Stanca L, Prognostic factors in anterior skull base meningiomas. Rom J Morphol Embryol., 2014; 55(3 Suppl): 1063-1069.

6. Fouad M, Helvenstein M, Blankert B, Ultra High Performance Liquid Chromatography Method for the Determination of Two Recently FDA Approved TKIs in Human Plasma Using Diode Array Detection. J Anal Meth Chem., 2015; Art. Id 215128: 1-6.

7. Jong J, Sukbuntherng J, Skee D, Murphy J, O’Brien S, Byrd JC, James D, Loury DJ, Jiao J, Chauhan V, Mannaert E, The effect of food on the pharmacokinetics of oral ibrutinib in healthy participants and patients with chronic lymphocytic leukemia. Cancer Chemother Pharmacol., 2015; 75(5): 907-916.

8. Morgovan C, Ghibu S, Juncan AM, Rus LL, Butucă A, Vonica L, Muntean A, Moş L, Gligor F, Olah NK, Nutrivigilance: A new activity in the field of dietary supplements. Farmacia, 2019; 67(3): 537-544.

9. Neamțu S, Găman G, Stanca L, Buzatu I, Dijmărescu L, Manolea M, The contribution of laboratory investigations in diagnosis of congenital infections. Rom J Morphol Embryol., 2011; 52(1 Suppl): 481-484.

10. Neamțu SD, Novac MB, Forțofoiu M, Forțofoiu MC, Siminel M, $16^{\text {th }}$ International Multidisciplinary Scientific GeoConference Sgem 2016. Advances in Biotechnology: 641.

11. O'Brien SM, Furman RR, Coutre SE, Flinn IW, Burger J, Blum K, Sharman J, Wierda WG, Jones J, Zhao W, Heerema NA, Johnson AJ, Luan Y, James DF, Chu AD, Byrd JC, Single-agent ibrutinib in treatmentnaïve and relapsed/refractory chronic lymphocytic leukemia: a 5-year experience. Blood, 2018; 131(17): 1910-1919.

12. Rood JJM, Dormans PJA, van Haren MJ, Schellens JHM, Beijnen JH, Sparidans RW, Bioanalysis of ibrutinib, and its dihydrodiol- and glutathione cycle metabolites by liquid chromatography-tandem mass spectrometry. J Chromatogr B., 2018; 1090: 14-21.

13. Rood JMM, Schellens JHM, Beijnen JH, Sparidans RW, Recent developments in the chromatographic 
bioanalysis of approved kinase inhibitor drugs in oncology. J Pharm Biomed Anal., 2016; 130: 244-263.

14. Rood JMM, Van Hoppe S, Schinkel AH, Schellens JHM, Beijnen JH, Liquid chromatography-tandem mass spectrometric assay for the simultaneous determination of the irreversible BTK inhibitor ibrutinib and its dihydrodiol-metabolite in plasma and its application in mouse pharmacokinetic studies. J Pharm Biomed Anal., 2016; 118: 123-131.

15. Siminel MA, Neamțu CO, Dițescu D, Forțofoiu MC, Comănescu AC, Novac MB, Neamţu SD, Gluhovschi A, Apert syndrome - clinical case. Rom J Morphol Embryol., 2017; 58(1): 277-280.

16. Vajjha S, Bommuluri V, Mohan PKVK, Rumalla CS, Doddipalla R, Kaliyaperumal M, Korupolu RB, Degradation studies of ibrutinib under stress conditions: Characterisation and structural elucidation of novel degradants. J Pharm Biomed Anal., 2019; 172: 9-17.
17. Veeraraghavan S, Viswanadha S, Thappali S, Govindarajulu B, Vakkalanka S, Rangasamy M, Simultaneous quantification of lenalidomide, ibrutinib and its active metabolite PCI-45227 in rat plasma by LC-MS/MS: application to a pharmacokinetic study. J Pharm Biomed Anal., 2015; 107: 151-158.

18. Zwart L, Snoeys J, Jong J, Sukbuntherng J, Mannaert EJ, Monshouwer M, Ibrutinib dosing strategies based on interaction potential of CYP3A4 perpetrators using physiologically based pharmacokinetic modelling. Clin Pharmacol Ther., 2016; 100(5): 551-562.

19. Yasu T, Momo K, Yasui H, Kuroda S, Simple Determination of Plasma Ibrutinib Concentration Using High-Performance Liquid Chromatography. Biomed Chromatogr., 2019; 33(3): e4435: 1-6. 